\title{
Removal of Chromium from Aqueous Solution using Multilayer- Mixed (Reduction/Sorption) Bed from Iron Scrap and Nutshells
}

\author{
Noor Saadi Mahdi ${ }^{1}$, and Hayder Mohammed Abdul Hameed ${ }^{2, *}$ \\ ${ }^{1}$ College of Engineering, University of Baghdad, Baghdad, Iraq, noooor_2018@yahoo.com \\ ${ }^{2}$ College of Engineering, University of Baghdad, Baghdad, Iraq, hayderadul_hameed@yahoo.com \\ *Corresponding author: Noor Saadi Mahdi,noooor_2018@yahoo.com \\ Published online: 30 June 2019
}

Abstract- In this research removal of chromium from an aqueous solution by multilayer-mixed (reduction/sorption) bed via scrap iron as zero valent iron and charred nutshell (walnut shell) as adsorber were studied. Both batch and continuous system were conducted. The batch system reveals that the adsorption process was of favorable type. Three models were used to describe the adsorption process. Freundlich model is matching well to the data with $(\mathrm{R} 2=0.975)$. In the continuous system , two sets of experimental were considered, the first set (multilayer bed) conducted by fixing the characteristics of the scrap iron bed (bed height $0.2 \mathrm{~cm}$, particle size $500 \mu \mathrm{m}$ ) and varying the walnut shell parameters, the optimum value of this set recorded as (bed height $2.5 \mathrm{~cm}$, particle size $250 \mu \mathrm{m}$ ). While for the second set of experimental after fixing the optimum values of the walnut shell bed and varying the scrap iron bed characteristics, the optimum values were (height $1 \mathrm{~cm}$, particle size $500 \mu \mathrm{m}$ as filling). Also, the Mixed bed configuration were studied by conducting the optimum conditions for the previous experiment. it was found that at any certain time the mixed layer offers the maximum efficiency of removal rather than the multilayer bed.

Keywords- Scrap iron, Chromium, adsorption, walnut shells.

\section{Introduction}

Environment pollution is a worldwide problem and have a great potential and influence to human health [7] [14]. Pollution reaches its most serious proportions in the densely settled urban-industrial centers of the more developed countries [10]. Heavy metals can be found in dissolved form, particulate and colloidal phases, the presence of metals in water bodies can be caused by either anthropogenic origin (e.g. waste water disposal) or natural origin (e.g. leaching of ore deposits) [3][11]. Chromium is a metal that have extremely importance and variety uses in industries like: textile dying, tanneries, metallurgy, chemical and refractory industries, wood preserving, preparation of chromate compounds, metal electroplating. Hexavalent Chromium $(\mathrm{Cr}+6)$ compounds show a high environmental mobility and have toxic effects in most living organisms [6]. Trivalent Chromium $(\mathrm{Cr}+3)$ is undesired metals that have adverse affects on human health and can accumulate in the food chain, that will because numerous diseases. Many industries use trivalent chromium $\mathrm{Cr}+3$ and disposed it from their effluent, such as electroplating, tanning and leather. In wastewater the max. level of $\mathrm{Cr}+3$ is $5 \mathrm{mg} / \mathrm{L}$ [4].

\section{Experimental work}

This study was done to assess the use of scrap iron fillings (as a zero valent iron) to continuously reduced of $\mathrm{Cr}+6$ to $\mathrm{Cr}+3$ and subsequent adsorption of $\mathrm{Cr}+3$ onto charred walnut shells. The effect of different factors and conditions on treatment process such as bed height and particle size of scrap iron and charred walnut shell, had been studied.

\subsection{1 Zero valent iron fillings}

Scrap iron filings was used in this study as a zero valent iron (ZVI, with oxidation number of zero, $\mathrm{Fe} 0$ ), type SELKA GmbH, Hamburg, Code 46 12.12, Germany.

\subsection{Preparation of adsorbent}

Walnut shells were collected from local markets and washed with de-ionized water for several times to remove 
impurities and dirts. Wetted Walnut shells were dried at $100{ }^{\circ} \mathrm{C}$ using electrical laboratory oven as reported by [12]. The dried Walnut shells were grinded and then charred in a laboratory furnace (type CARBOLITE-CWF 1200) set of $\left(600{ }^{\circ} \mathrm{C}\right)$ for $(1 \mathrm{~h})$ [12]. The resulted charred walnut shells were sieved to $(250 \mu \mathrm{m}, 600 \mu \mathrm{m}, 1 \mathrm{~mm})$ size using (Sieves type, S/N:0307314, Body size $(200 \times 500) \mathrm{mm}$, Made in Germany) to study the effect of changing the particle size on adsorption process.

\subsection{Contaminant}

The stock solution of chromium with concentration of (1000)ppm (mg/L) was set through dissolving (5.6584)g of $(\mathrm{K} 2 \mathrm{Cr} 2 \mathrm{O} 7)$ potassium dichromate in (1L) volume of deionized water. Prepared stock solution was diluted finally to get the desired concentration of chromium ions, by using equation (1) [15].

$$
W=C^{*} V^{*}\left(M_{-}(w t)\right) / \llbracket A t \rrbracket_{-}(w t)
$$

Where:

$$
\begin{aligned}
& \mathrm{W} \text { : the metal mass of } \mathrm{K} 2 \mathrm{Cr} 2 \mathrm{O} 7 \quad(\mathrm{mg}) \\
& \mathrm{C} \text { : the required concentration }(\mathrm{mg} / \mathrm{L}) \\
& \mathrm{V} \quad \text { : solution volume in }(\mathrm{L})
\end{aligned}
$$$$
\text { At wt : the atomic weight, } \mathrm{Cr}=\quad 51.99 \mathrm{gm} / \mathrm{mole}
$$

$\mathscr{M} w \mathrm{wt}$ : the molecular weight, for potassium dichromate= $294.1846 \mathrm{gm} / \mathrm{mole}$.

\subsection{Batch Experiment}

Batch experiment was conducted by using constant mass of one of the two waste materials with different masses for the second material; (e.g. adding $0.5 \mathrm{gm}$ of scrap iron to $(0.2,0.4,0.6,0.8,1,1.2,1.4,1.6,1.8,2 \mathrm{gm})$ of char prepared from walnut shells, then using the optimum dose of the char with different masses of scrap iron $(0.1,0.2,0.3,0.4,0.5,0.6,0.7,0.8,0.9,1 \mathrm{gm})$. Stock solution was diluted to obtain the needed concentration $(25$ $\mathrm{mg} / \mathrm{L}$ ) of chromium ion.

Samplesof $(100 \mathrm{ml})$ of the -known concentrationsolution were placed in flasks (conical), with accurate masses of walnuts waste adsorbent and scrap iron. $\mathrm{pH}=7$ (was measured), temperature $=25 \mathrm{oC}$. After that 10 flasks were put in rotary shaker (No.SM-25, Edmund, Made in Germany) with speed of agitation (100rpm) for 24 hours.

\subsection{Continuous System}

Glass tube of length $(35 \mathrm{~cm})$ and inner diameter $(4.5 \mathrm{~cm})$, was used with distributer to insure a good distribution of the solution over the bed. Glass mesh also was used for preventing the materials losses. When the run is on, the solution of Chromium -with known concentration- was passed through the bed. (40L) volume plastic container was used for containing the stock solution. A flow meter was used for measuring the flow rate. Electrical pump(HP9600D) was used to pump the chromium solution from the feed solution to the bed. The bed is packed with scrap iron and charred walnut shells in two systems (separated and mixed).

\section{Results and discussion}

\subsection{Batch system}

To identify the adsorption isotherm, batch process was carried out to investigate the type of agricultural waste adsorbent (charred walnut shell) equilibrium isotherm relation.

Table 1: Equilibrium isotherms for the systems of chromium ions at $\mathrm{Co}=25 \mathrm{mg} / \mathrm{L}$ onto charred walnut shell adsorbent, $\mathrm{pH}=7$, contact time $=24 \mathrm{~h}$, agitation speed $=100 \mathrm{rpm}$ and temperature $=25^{\circ} \mathrm{C}$.

\begin{tabular}{|c|c|c|c|}
\hline $\begin{array}{c}\text { Weight of } \\
\text { scrap iron } \\
(\mathrm{g})\end{array}$ & $\begin{array}{c}\text { Weight of } \\
\text { charred } \\
\text { walnut shell } \\
\text { adsorbent } \\
(\mathrm{g})\end{array}$ & $\mathrm{C}_{\mathrm{e}}(\mathrm{mg} / \mathrm{L})$ & $\mathrm{q}_{\mathrm{e}}(\mathrm{mg} / \mathrm{g})$ \\
\hline 1 & 0.2 & 16 & 4.5 \\
\hline 1 & 0.4 & 9.1 & 3.975 \\
\hline 1 & 0.6 & 6.1 & 3.15 \\
\hline 1 & 0.8 & 4.21 & 2.59875 \\
\hline 1 & 1 & 3.5 & 2.15 \\
\hline 1 & 1.2 & 2.6 & 1.86667 \\
\hline 1 & 1.4 & 2.4 & 1.61429 \\
\hline 1 & 1.6 & 1.5 & 1.46875 \\
\hline 1 & 1.8 & 1.3 & 1.31667 \\
\hline 1 & 2 & 0.9 & 1.205 \\
\hline
\end{tabular}

Experimental data for batch experiment was fitted to Langmuir and Freundlich isotherm (equations 2, 3 respectively).

$$
\mathbf{q}_{\mathbf{e}}=\frac{\mathbf{q}_{\max } * \mathbf{b} * \mathbf{C}_{\mathbf{e}}}{\left(1+\mathbf{b} * \mathbf{C}_{\mathbf{e}}\right)}
$$

Where:

qe : adsorption capacity at equilibrium $(\mathrm{mg} / \mathrm{g})$.

Ce : concentration of metal ions remaining in solution at equilibrium $(\mathrm{mg} / \mathrm{L})$.

qmax: maximum amount of metal ion per unit mass of adsorbent to form a complete monolayer $(\mathrm{mg} / \mathrm{g})$.

b : adsorption equilibrium constant $(\mathrm{L} / \mathrm{mg})$.

$$
\mathrm{q}_{\mathrm{e}}=\mathrm{KC}_{\mathrm{e}} \mathrm{e}^{1 / \mathrm{n}}
$$

Where:

$\mathrm{Ce}$ : The concentration of metal ions remaining in solution at equilibrium $(\mathrm{mg} / \mathrm{L})$. 
qe : The amount of metal ions adsorbed $(\mathrm{mg} / \mathrm{g})$.

$\mathrm{K}$ and $\mathrm{n}$ are Freundlich's adsorption constants.

$1 / \mathrm{n}$ : is surface heterogeneity or the adsorption intensity.

It was found that Freundlich isotherm gave the best fitting according to R2 value which was equals to (0.975).

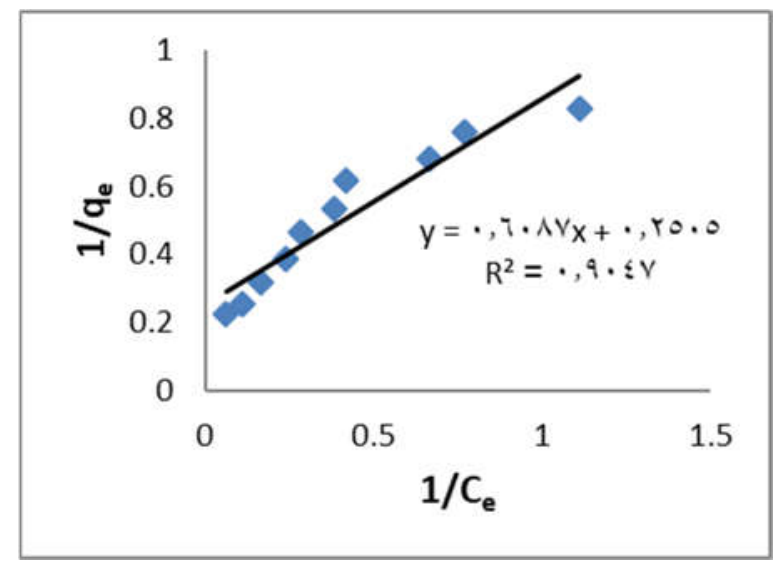

Figure 1 : Langmuir model.

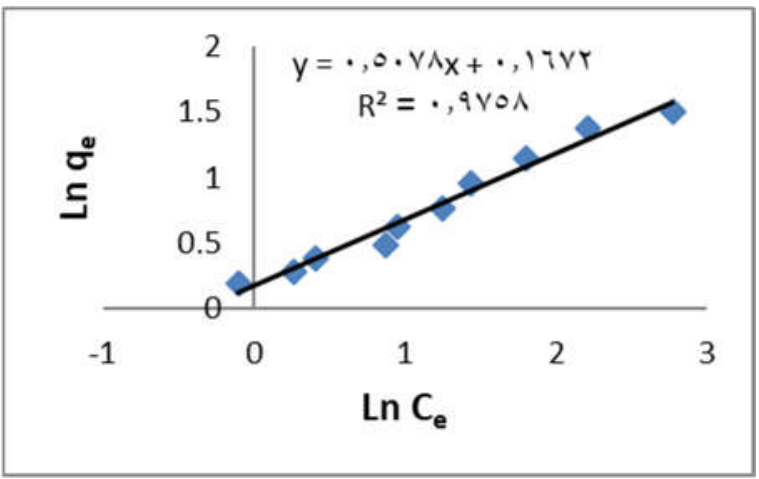

Figure 2 : Freundhich model.

\subsection{Continuous system}

In the continuous operational systems different parameters were studied, shown in table 2 :

Table 2: Experimental parameters

\begin{tabular}{|c|c|c|}
\hline \multirow{2}{*}{ Bed height } & $\begin{array}{c}\text { Charred walnut } \\
\text { shell }\end{array}$ & Scrap iron \\
\cline { 2 - 3 } & $0.5,1,15,2,2.5 \mathrm{~cm}$ & $\begin{array}{c}0.2,0.5,1 \\
\mathrm{~cm}\end{array}$ \\
\hline Particle size & $\begin{array}{c}250 \mu \mathrm{m}, 600 \mu \mathrm{m}, \\
1 \mathrm{~mm}\end{array}$ & $\begin{array}{c}500 \mu \mathrm{m},(3- \\
3.5 \mathrm{~mm})\end{array}$ \\
\hline
\end{tabular}

\subsubsection{Effect of bed height of charred walnut adsorbent}

The effect of varying the bed height of the charred walnut shell adsorbent $(0.5,1,1.5,2,2.5 \mathrm{~cm})$ was conducted by fixing these parameters (bed height and particle size of scrap iron as $(0.2) \mathrm{cm}$, and $(500) \mu \mathrm{m}$ respectively. The particle size of the charred walnut shell adsorbent was
$600 \mu \mathrm{m}$. Initial concentration was $\mathrm{Co} 25(\mathrm{mg} / \mathrm{L})$. the temperature $25^{\circ} \mathrm{C}$. $\mathrm{pH} 5.8$ and flow rate $0.5 \mathrm{~L} / \mathrm{hr}$. The experimental breakthrough curves are presented in Fig.3 as $\mathrm{Ce} / \mathrm{Co}$ versus time.

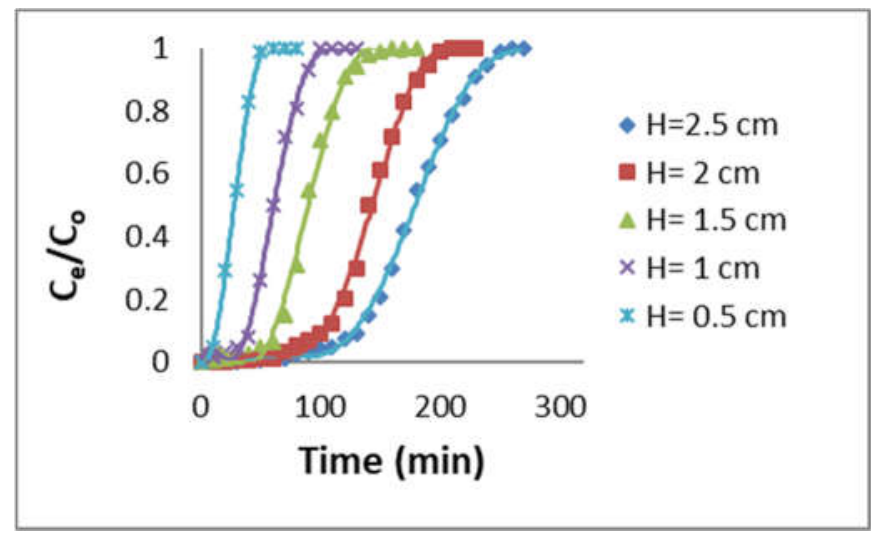

Figure 3: Breakthrough curves for different bed height of charred walnut shells adsorbent.

From this figure it is clear that when the height of bed increases, the breakpoint (in the breakthrough curve) increases. The reason is, as bed height is larg the ratio of adsorbate concentration in the effluent will be increasing slower than for a smaller bed height. Moreover, the time for saturation is increases. Greater bed heights correspond to greater mass of an adsorbent, as a result, a greater capacity for bed [5].

- Increasing the bed height will increase the contact time of the adsorbate with the bed, thus the adsorbate removal efficiency will improve. As the bed height increases, the adsorption capacity will increase too, which corresponds to extra spaces on charred walnut shell active sites. These sites will be available for the adsorbate molecules for adsorpting on these empty active sites[1].

\subsubsection{Effect of particle size of charred walnut adsorbent}

The effect of using various particle sizes $(250 \mu \mathrm{m}$, $600 \mu \mathrm{m}, 1 \mathrm{~mm}$ ) of charred walnut shell on the breakthrough curves were investigated with fixing the other parameters. Bed height of charred walnut shell was $2.5 \mathrm{~cm}$. Initial concentration Co was $25 \mathrm{mg} / \mathrm{L}$. Temperature was $25^{\circ} \mathrm{C}$, $\mathrm{pH}$ was 5.8 and flow rate was $0.5 \mathrm{~L} / \mathrm{hr}$. Experimental breakthrough curves are shown in Fig. 4. 


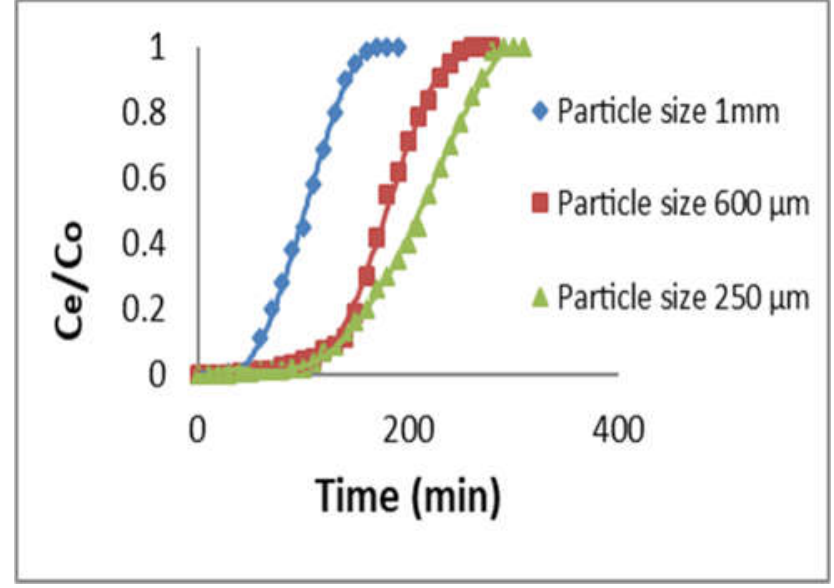

Figure 4: Breakthrough curves for different particle size of charred walnut shells adsorbent.

The breakthrough curves indicated that the time required for reaching breakpoint increases when particle size decreases. This occurs because that surface area available for adsorption increase with decreasing the particle size. That means more sites for adsorption and the adsorption capacity increases Figure (4) reveals that, as the particle size decreases, it will increase the time for saturation, and the film thickness that can be found around the adsorbent particle is increased. Also, inside the pore structure, the length of the path also increases. This will make the process kinetics low, the adsorbate molecules

will need more time to reach the active site on adsorbent, since the larger diffusion path inside the pores[2].

\subsection{3-Effect of bed height of scrap iron}

Three experiments were conducted for different bed height of scrap iron $(0.2,0.5,1 \mathrm{~cm})$ to examine breakthrough curves, with optimum conditions from the previous experiments. Experimental breakthrough curves are plotted in Fig.5.

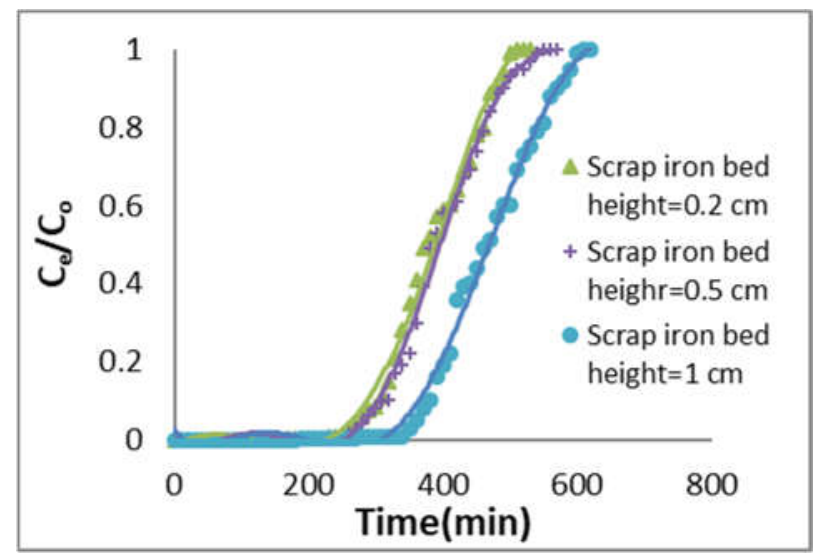

Figure 5: Breakthrough curves for different bed height of scrap iron.

As it was observed from figure as the bed height of scrap iron increases, the breakpoint increases. The sorption capacity increases also as the bed height increases. This can be attributed to the increase in specific surface of the sorbent (more binding sites), that will cause a delay in the breakthrough of the pollutant In addition, the time required for saturation and breakthrough are increased for long columns, as reported by [13].

\subsubsection{Effect of shape and size of scrap iron}

Effect of using different particle shape (spiral, fillings) Fig. 6,7 respectively,

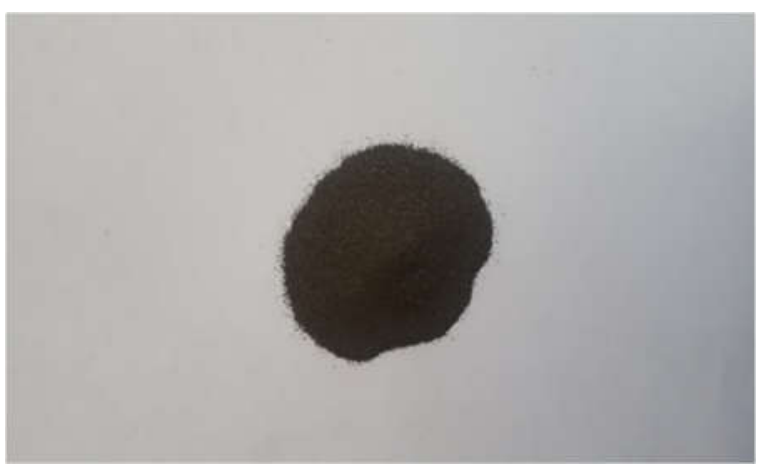

Figure 6 :Scrap iron Filling.

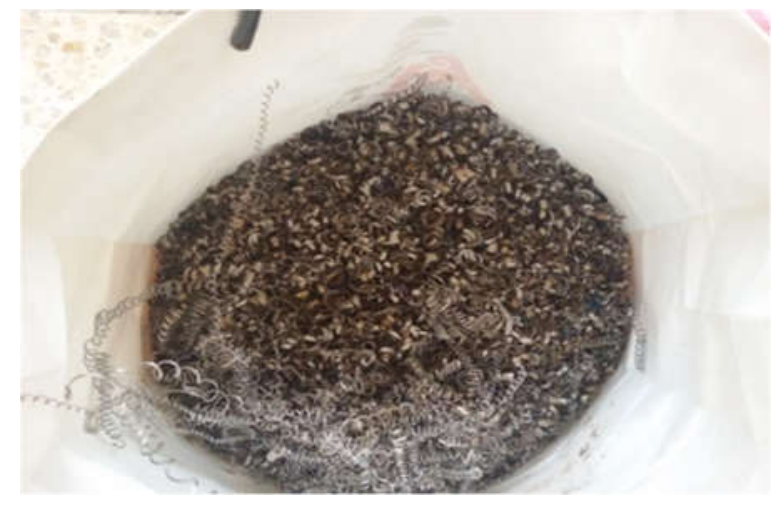

Figure 7: Scrap iron spiral.

With dimensions (length 3-7 $\mathrm{mm}$ and diameter 3-3.5 mm) for spiral, and $(500 \mu \mathrm{m})$ for fillings scrap iron, on the breakthrough curves were studied by keeping the other parameters constant. Experimental breakthrough curves are presented in Fig.8.

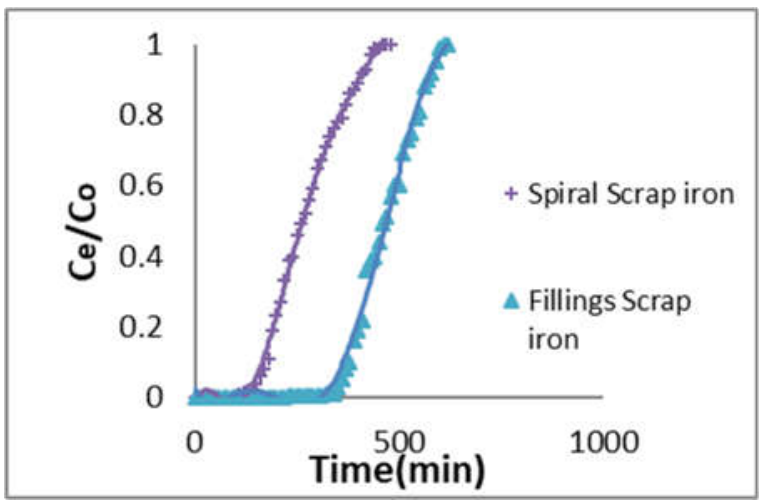

Figure 8: Breakthrough curves for different particle size of scrap iron 
The previous figure indicated that when particle size of scrap iron decreases, the breakpoint will be increased. This is attributed to increasing the surface area needed for reduction. When the particle size decreases, additional sites would be available for solute and the reduction capacity increases [8].

\section{Conclusions}

1- scrap iron filings (ZVI) offers a good media for reduction of $\mathrm{Cr}+6$ to $\mathrm{Cr}+3$, and charred walnut shell act as a good recycled, charred media for adsorption of chromium from aqueous solution.

2- Fruendlich model describe well the adsorption data as this indicates a good agreement with the published studied and research in this field.

3- The removal efficiency of $\mathrm{Cr}$ increase with bed height, decrease in particle size for both scrap iron and walnut shell.

4- Using these waste materials (scrap iron and charred walnut shell) offering low cost alternatives for the conventional expensive methods in chromium removal from aqueous solution, and sustainable development benefits in terms of reuse of solid waste as well as a means of reduction disposal costs.

\section{References}

[1] Abdul-Hameed, H. M., 2009, "Competitive Adsorption of Heavy Metals onto Activated Carbon in Fixed Bed Columns", University of Baghdad, College of Engineering, Ph.D. Thesis.

[2] Abdul-Kareem, R., 2014, "Sustainable Production of Local Adsorbent Material from Waste Tires for Removal of Lead from Aqueous Solution", University of Baghdad, College of Engineering, M.Sc. Thesis.

[3] Adepoju-Bello, A. A., Ojomolade, O. O., Ayoola, G. A., Coker, H. A. B., 2009, "Quantitative analysis of some toxic metals in domestic water obtained from Lagos metropolis", The Nig. J. Pharm, vol. 42(1), pp. 57-60.

[4] Akrim, M. A., 2015, "Removal of Chromium and Red Dye from simulated wastewater by adsorption onto Cement Kiln Dust", University of Baghdad, College of Engineering, M.Sc. Thesis.

[5] Baral, S. S., Das, S. N., Rath, P., 2006, "Hexavalent chromium removal from aqueous solution by adsorption on treated sawdust", Biochemical Engineering Journal, vol.31(3), pp.216-222.
[6] Das, A. P., Mishra, S., 2008, "Hexavalent Chromium (VI) : Environmental Pollutants and Health Hazard", Journal of Environmental Research And Development, vol. 2, pp. 386-392.

[7] Fereidoun, H., Nourddin, M. S., Rreza, N. A., Mohsen, A., Ahmad, R., and Pouria, H., 2007, "The Effect of LongTerm Exposure to Particulate Pollution on the Lung Function of Teheranian and Zanjanian Students", Pakistan Journal of Physiology, vol. 3(2), pp. 1-5.

[8] Gheju, M., 2011, "Hexavalent Chromium Reduction with Zero-Valent Iron (ZVI) in Aquatic Systems", Water Air Soil Pollut, vol. 222, pp. 103-148.

[9] Hand, D. W., Crittenden, J. C., Hokanson, D. R., Bulloch, J. L., 1997, "Predicting the performance of fixedbed granular activated carbon adsorbers", Water Scince and Technology, vol. 35, pp. 235-241.

[10] Kromm, D. E., 1973, "Response to Air Pollution in Ljubljana, Yugoslavia", Annals of the Association of American Geographers, vol. 63(2), pp. 208-217.

[11] Marcovecchio, J. E., Botte, S. E., Freije, R. H., 2007, "Heavy Metals, major metals, trace elements, handbook of water analysis", L. M. Nollet, 2nd. Ed., London: CRC Press, pp. 275-311.

[12] Mart'inez, M. L., Torres, M. M., Guzm'an, C. A., Maestri, D. M., 2006, " Preparation and characteristics of activated carbon from olive stones and walnut shells", Industrial Crops and Products, vol. 23, pp. 23-28.

[13] Mohammed, R. J., 2017, "Effect of $\mathrm{pH}$ on the performance of Permeable reactive barrier through the migration of lead-contaminated groundwater", MS.c. Thesis.

[14] Progressive Insurance, 2005, "Pollution Impact on Human Health", Retrieved fromhttp://www.progressiveic.com/n25feb05.htm.

[15] Ridha, M. J., 2011, "Competitive Biosorption of Heavy Metals Using Expanded Granular sludge bed reactor", College of Engineering, University of Baghdad, PhD. Thesis. 
إزالة الكروم من المحلول المائي باستخدام مفاعل منعدد الطبقات_مختلط بتقنيتي (الاختز ال /الأمتز ازم) وباستخدام سكر اب الحديد كمادة مختزلة وقتشور المكسر ات كمادة ممتزة

\section{نور سعدي مهاي 1، حير محد عب الحمبي 2"}

جامعة بغداد ، كلية العندسة ، بغداد، العراق ، noooor_2018@yahoo.com

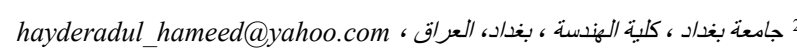
" الباحث المثل: نور سعدي مهدي ، البريب الاكتروني: noooor_2018@yahoo.com نشر في: 30 حزيران 2019

الخلاصة ـ في هذا البحث يتم از الة ايونات الكروم من المحلول المائي باستخدام مفاعل متعدد الطبقاتـ مختلط بتقنيتي (الاختز ال/الامتز از) وباستخدام

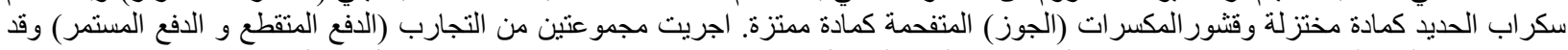

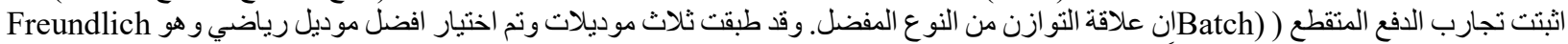

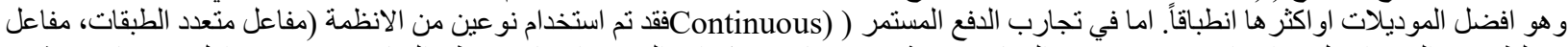

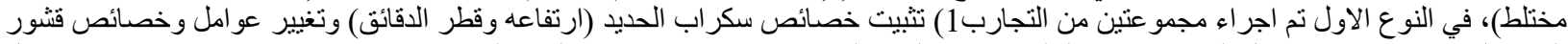

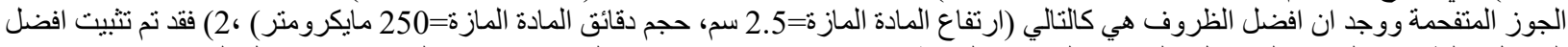

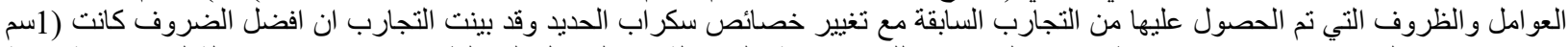

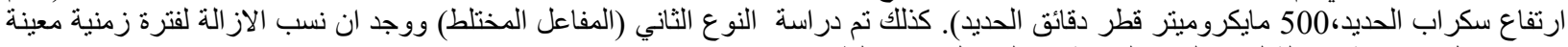

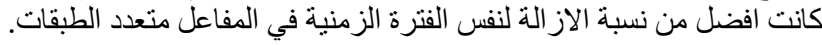
الكلمات الرئيسية ـ سكر اب الحديد، الكروم، الامتزاز، قثور الجوز. 